\title{
Large Scale Demonstration of Improved Rice Technologies towards Commercialization through Cluster Approach in the Districts of Lake Tana belt, North Western Ethiopia
}

\author{
Misganaw Anteneh*, Endayen Melaku, Seged Ayichew \\ Fogera National Rice Research Center, P.O.Box, 1937, Woreta, Ethiopia
}

*Corresponding Authors: Misganaw Anteneh, Fogera National Rice Research Center, P.O.Box, 1937, Woreta, Ethiopia

\begin{abstract}
Large Scale Demonstration using clustered farms has recently become popular extension approach with its own convincing rationale and important lessons learnt from previous extension interventions. Some of important values of Large Scale Demonstration approach as compared with Small Scale Demonstration on scattered plots are: cost effective in terms of labor, time, energy and money, creates learning platform and strong feeling of competition among farmers, easy to manage and provide mechanization services, follow-up and evaluation, address large clients or technology beneficiaries at a given time, strengthen social capital in terms of contact and communication between farmers and other actors. The activity was mainly conducted in lowland rice production system at six districts located around Lake tana belt. 436 farmers were benefited from this intervention on 145 hectares of land clustered on 14 sites. Shaga and wanzaye improved rice varieties were used under demonstration in the lowland rice production system. Areas around the belts of Lake Tana are huge and untapped potential of lowland rice production system which covers the majority of national supply. Majority of smallholder farmers in these areas are relied on traditional based rice production using local varieties and their own indigenous agronomic practices on scattered plots system. Yield measurement has been undertaken on demonstrated varieties using quadrant estimation method. Based on this estimation of productivity per hectare across districts both improved varieties (Shaga and/or Wanzaye) had been by far better than the local ones. The strength of association $\left(\omega^{2}\right)$ between the dependent variable (productivity) and independent variable (three groups of varieties) accounts for approximately $46 \%$ of the variance on the dependent variable. The level of varieties is significantly different which results to effect on productivity significantly, $\boldsymbol{F}(\mathbf{2}, \mathbf{6})=\mathbf{5 . 7}, \boldsymbol{p}<\mathbf{0 . 0 5}$. Grain color of wanzaye and shaga has been still a big issue by farmers and hence concerned researchers particularly breeding research team need to improve its grain color or release other new and good grain color varieties. Integration among different stack holders in rice promotion and value chain development is crucial to achieve the final goals of the country in rice sector.
\end{abstract}

Keywords: Cluster, Demonstration, Lake Tana, lowland, Shaga, Wanzaye

\section{BACKGROUND AND JUSTIFICATION}

Efforts to introduce rice had probably been started in Ethiopia when the wild rice (O. longistaminata) was observed in the swampy and waterlogged areas of Fogera and Gambella plains (Gebeyet al., 2012). Despite being introduced only recently, rice has proven to be a crop that can assure food security in Ethiopia (Astewl, 2010). There is an increasing trend of expansion in both area and production of the crop (MoARD, 2010; CSA, 2011; Gebeyet al., 2012). The area under rice and the number of farmers engaged in rice production are growing year after year. Currently, Amhara, Southern Nations, Nationalities and Peoples Region (SNNPR), Oromia, Somali, Gambella, BenishangulGumuz, and Tigray regions are rice producing areas in Ethiopia (MoARD, 2010).

According to the report of MoARD (2010), the potential rice production area in Ethiopia is estimated to be about 39,354,190 hectares, of which 5,590,895 ha is highly suitable, 24,910,629 ha suitable and $8,852,666$ is moderately suitable. Most of Ethiopia's rice production potential area lies in the western part of the country. However, the amount of area under rice cultivation in Ethiopia is low as compared to the potential. Beside its higher yield per unit area, rice has a higher market value. Generally, rice has great potential and can play a critical role in contributing to food and nutritional security, income generation, poverty alleviation and socio-economic growth in Ethiopia. 
Rice in Ethiopia is one of strategic food security commodities of the country. Rice production has brought a significant change in the livelihood of farmers and created job opportunities for citizens in different areas of the country. At the Fogera plain, rice plays an important role in relaxing the problem of food-insecurity of the farming community (Astewl, 2010). Before the introduction of rice, farmers in the Fogera plain were mainly engaged in livestock raring and few levels of crops production using residual moistures. Since the area is waterlogged during the main rainy season, it was unsuitable for crops production (Tilahunet al, 2018). The engagement in the rice production has transformed the lives of the farmers in the area. Moreover, significant number of private business persons have improved their lives by getting involved in rice processing and marketing (Dawitet al., 2018).

There is a considerably higher rate of rice imports compared to domestic production, which has results in considerable decline of the rate of self-sufficiency in rice consumption in Ethiopia. The estimated rate indicates that self-sufficiency in rice consumption in Ethiopia has decreased from about $70 \%$ in 2008 to about $30 \%$ in 2016 (FAOSTAT).

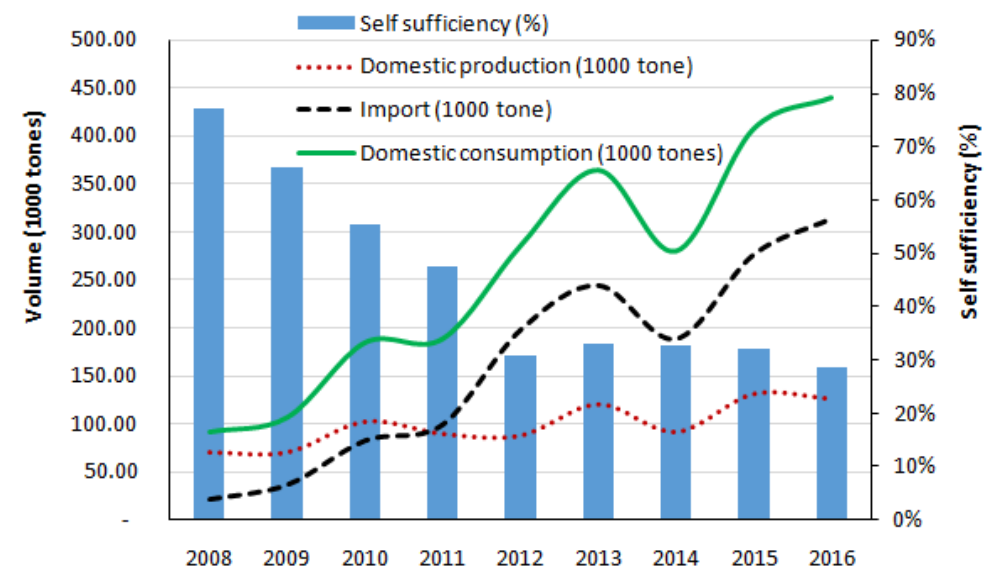

Figure1. Trends in rice production, imports, consumption and level of self-sufficiency (2008 - 2016)

The huge gap between the consumption and domestic supply of rice indicate that there is a big domestic market opportunity for rice producers. On the other hand, the big rice production potential of the country gives the opportunity to work more on the promotion of rice production in the country. To this end, the national rice research program tried to explore new and emerging traditional rice producing areas in view of assessing the potentials and challenges of rice production in those areas. It has been clear that there are huge potentials for rice production in various districts especially in and around Lake Tana belts/basin. These include, Bahir Dar City Administration, GonderZuria, North Achefer, Takusa, Alefa, East Dembia, West Dembia, Gondar Zuria, Ebnat, The rice production in major growing areas of Fogera, Libo-Kemkem and Dera is relatively well backed and addressed by the research and extension. However, the production in the new areas is not supported by the research and extension so far. Despite the huge potential and the interest of farmers in the area, the rice production is very limited because of the absence of improved technologies, extension support and post-harvest technologies to the areas. Recognizing the weak research and extension support to the new rice growing areas, this intervention was proposed with objectives to promoterice production, improve productivity and livelihood of producers in these areas located at LakeTana belts

\section{OBJECTIVES}

\subsection{Learning Objectives}

- To create wider demand on improved rice technologies

- To create and strengthen linkage among possible actors

- To enhance technology multiplication and dissemination systems

- To improve Knowledge and skill of farmers and Development agents

\subsection{Production Objectives}

- To improve rice production and productivity

- To enhance livelihood of rice producing households 


\section{Methodology (Materials, Methods)}

\subsection{Materials}

The activity was conducted in both upland and lowland rice ecosystems. For the lowland ecology Shaga, and Wanzayevarieties were used in the target areas of Dera, Bahir Darcity administration, North Achefer, Takusa,GonderZuria,and Fogera districts. For the upland ecology Fogera 1 and Adetvarieties were used. In each target kebele 5-40 ha of land were covered in clusters and for each cluster 20 to 64 farmers were participated.A seed rate of 100 quintals per hectare was used as per the recommendation. Training on the contents of improved rice production, agronomic practices, disease and pest management has been given by different multidisciplinary researchers from FogeraNational Rice Research Center. Farmers, DAs and experts from district offices were involved in the training. The seed was sown by the farmers with close follow up of the researchers, agricultural experts and development agents. Joint monitoring and evaluation through multidisciplinary approach has been conducted through different stages of the crop growth. Field days were organized at physiological maturity stage of the crop in the presence of participating farmers, agricultural experts, researchers and invited stakeholders. Feedbacks were collected and taken during monitoring and field day events.

\subsection{Methods of Data Collection}

Sorts of methods of data collection were used to gather different parameters, feedbacks and perception of stakeholders. Participatory data collection methods including Focused Group Discussion (FGD), Key Informants Interview, field observation and measurements

\subsection{Data Types}

Both quantitative and qualitative types of data were gathered. Quantitative data were collected on grain yieldusing quadrant technique (1meter $\mathrm{x} 1$ meter) on evenly spaced spots per site to check the comparative advantage of improved varieties against localvarieties, a number of participants in field days and beneficiary farmers on the technology by sex disaggregation. On the other hand qualitative data were collected on farmers' opinions, perception and feedbacks on demonstrated technology in comparing with their locally available varieties.Best experiences and success factors were identified.

\subsection{Method of Data Analysis}

The collected data have been analyzed applying descriptive and inferential statistics using Statistical Package for Social Science (SPSS) and Excel sheet.Descriptive statistics such as Mean, charts,percentage, frequency and table were applied.

\subsection{Location and Farmers Selection Methods}

Districts located at the belts of Lake Tana were identified through multi-disciplinary research for Extension intervention. Based on the assessment, gaps and needs of research and extension serviceswere identified so as to intervene through Large Scale Demonstration in those rice producing areas. The participating farmers were selected with the full awarenessand involvement of district and kebele level agriculture offices based on farmers' interest to use the full package of improved rice technologies.

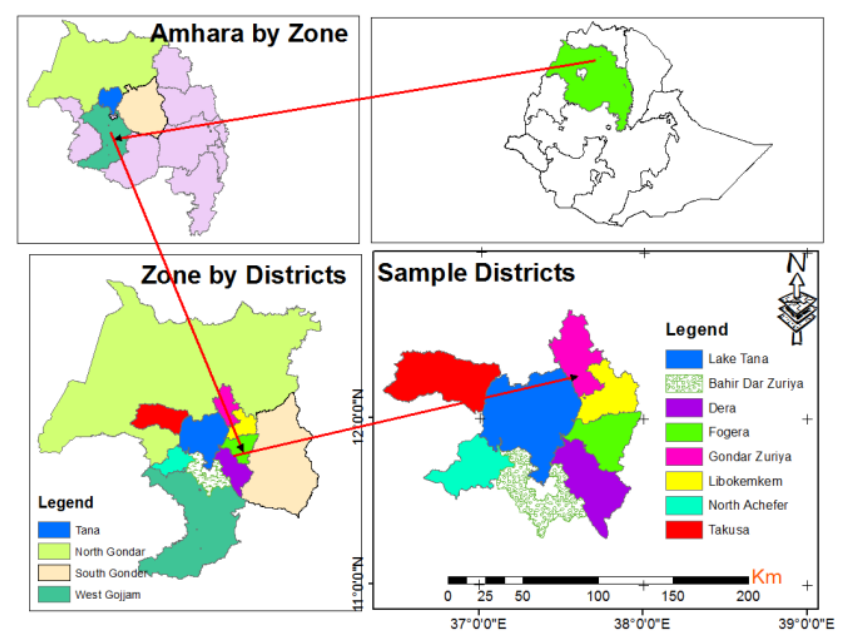

Figure2. Districts of extension intervention in the belts of Lake Tana 


\section{RESUltS AND DisCUSSION}

\subsection{Capacity Building}

Training is one of the components of capacity building and research-extension activities. Training on the contents of improved rice production, agronomic practices, Characteristics of improved rice varieties, disease and pest management, as well as extension techniques and clustering approaches have been given by different multidisciplinary researchers from Fogera National Rice Research Center. Farmers, DAs and experts from district offices were involved in the training. This training has been given for 526 farmers and 42 development agents and agricultural experts.Gender issue was taken under consideration during capacity building activities in both participants of farmers and Development agents/agricultural experts. From the total participant farmers in the training, 98 of them are female farmers which is almost $23 \%$ and 428 are male farmers.

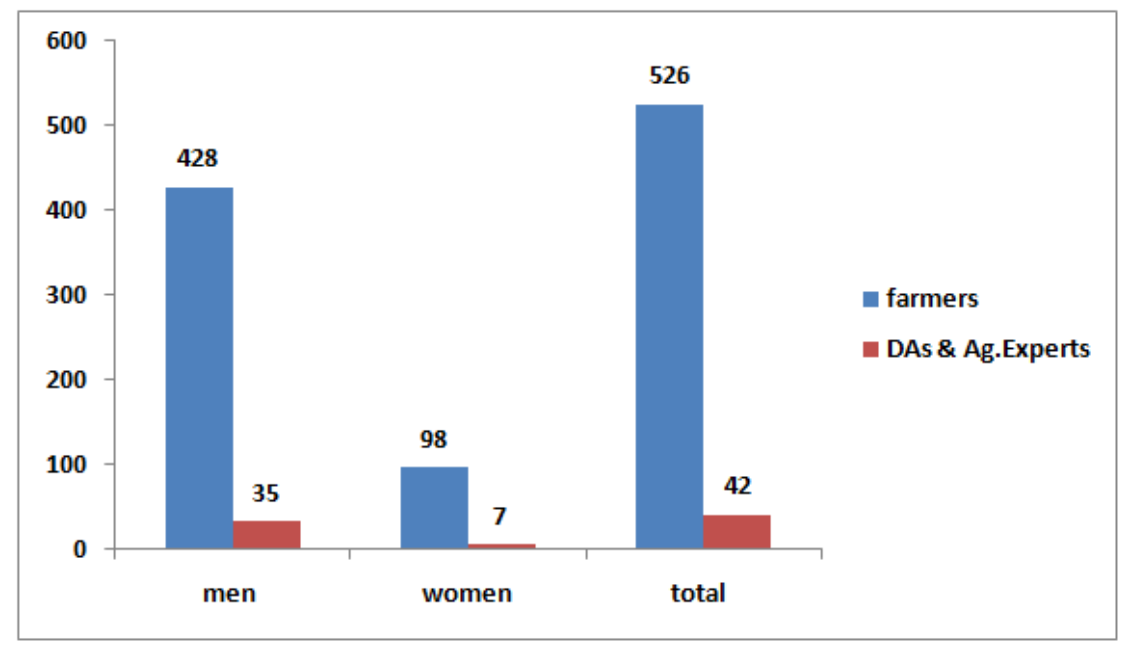

Figure3. Participants of capacity building through technical training by sex-disaggregation

\subsection{Field-Day}

Field day is one of the mechanisms of research and extension to get feedbacks on demonstrated activities at farmers' field and on station. In this case, different levels of field days have been organized to collect feedbacks, perception and preference on demonstrated technologies. Moreover, National field day has been organized and different stakeholders had been involved in the event and gave their feedbacks, perception and preference. A total of 900 farmers participated in different field day events and 80 development agents and agricultural experts. 850 male farmersand 50 female farmers were participated. 72 male and 8 female developments and agricultural experts.

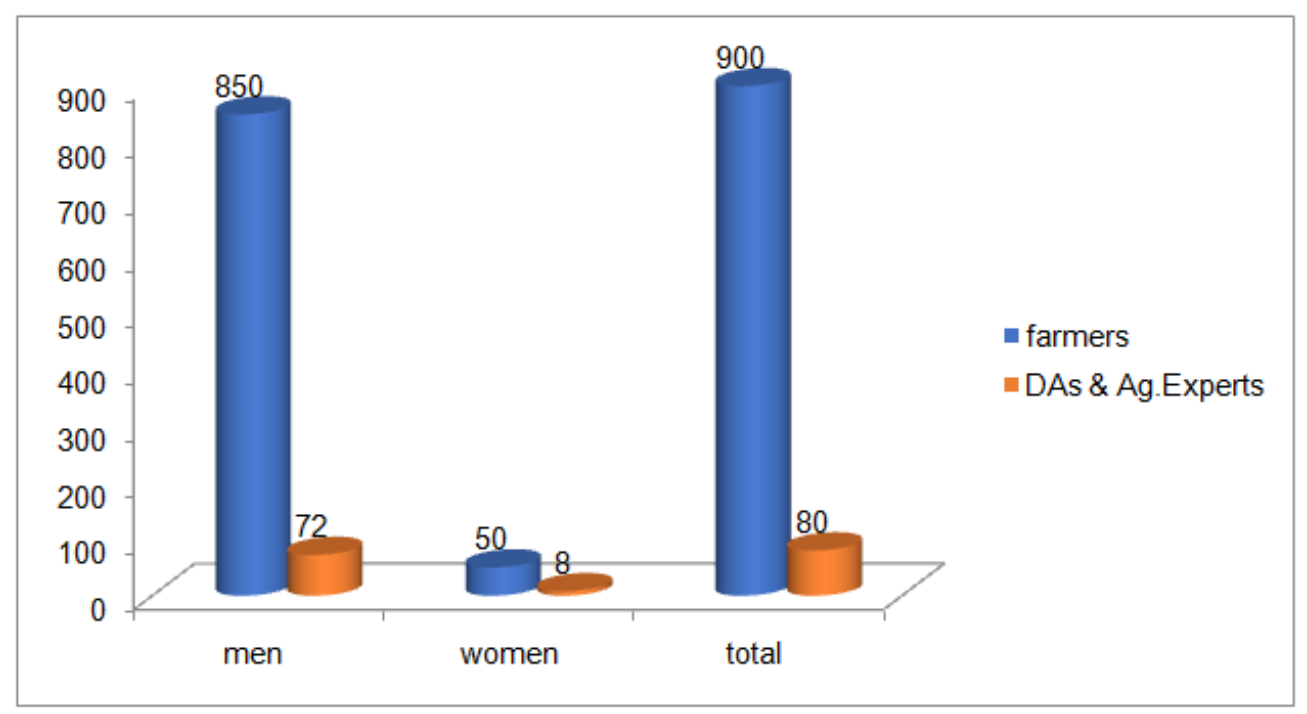

Figure4. summary of Participants of field-day 


\subsection{Cluster Size and Technology-Beneficiaries Disaggregated by Zones}

Cluster size of Large Scale Demonstration, technology beneficiaries and number of cluster sites have been identified and disaggregated by Zonal destinations. The zonal destinations are Central Gondar, South Gondar and West Gojjam of Amhara region. 145 hectares of land have been covered through Large Scale Demonstration (LSD) with 436 beneficiary farmers ona total 14cluster based locations. From this 54 ha found in Central Gondar Zone with 169 beneficiary farmers and7 cluster based locations and33 ha in South Gondar Zone with 151 beneficiaries on 4cluster based locationsand 58 ha in West GojjamZone with116 beneficiary farmers and 3 cluster locations.Central Gondar Zone took the first rank in terms of total size of clusters, technology beneficiaries and number of cluster based locations as compared with South Gondar and West Gojjam zones.

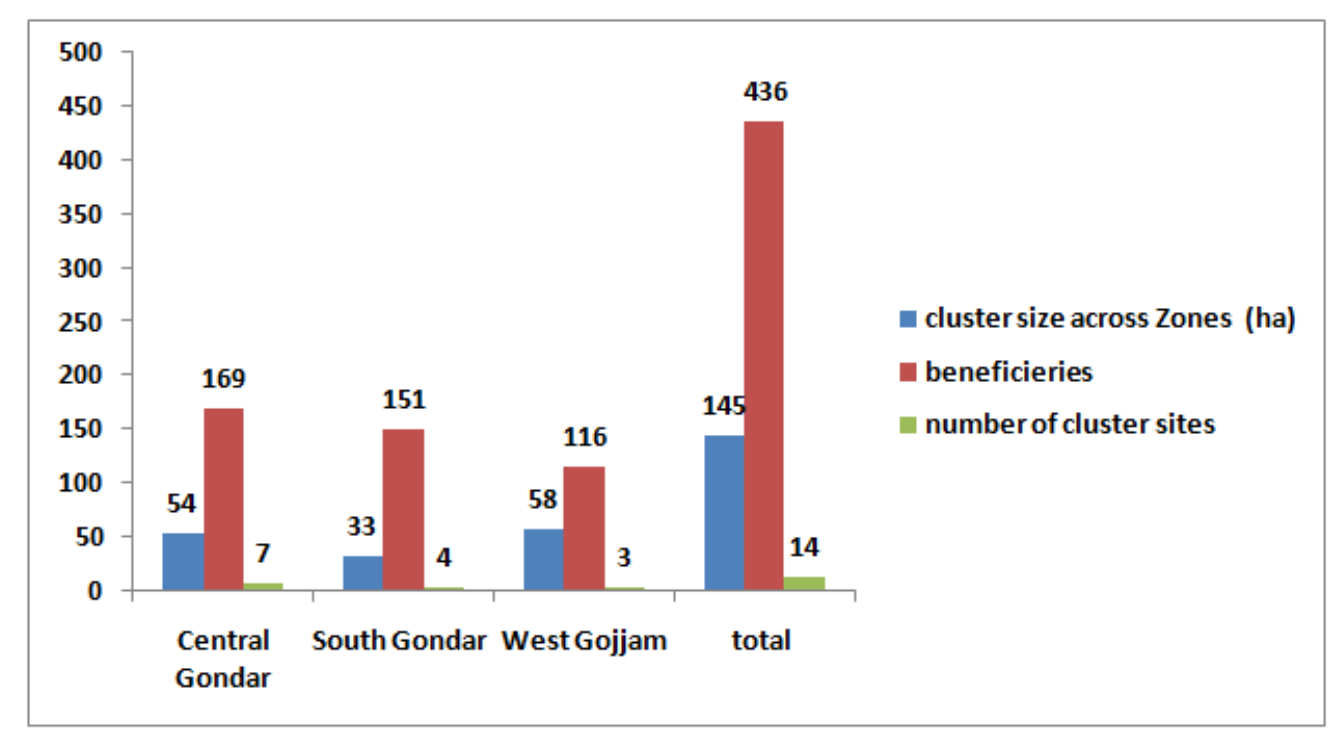

Figure5. Cluster size, technology beneficiaries and number of cluster locationsby zones

\subsection{Cluster Size and Beneficiaries Disaggregated by Districts}

The activity (LSD) has been conducted on a total of 6 districts such as Gondar zuria, Libokemkem, North achefer, Takusa, Bahir Dar City and Dera. These districts are very closely located around the belts of the Lake Tana which brought opportunities for potential of rice production due to overflow of water from the lake and other tributary rivers. Gondar zuria and Dera districts have taken the first and second ranks respectively in terms of size of total clusters and technology beneficiaries (farmers) in this Large Scale Demonstration activity.

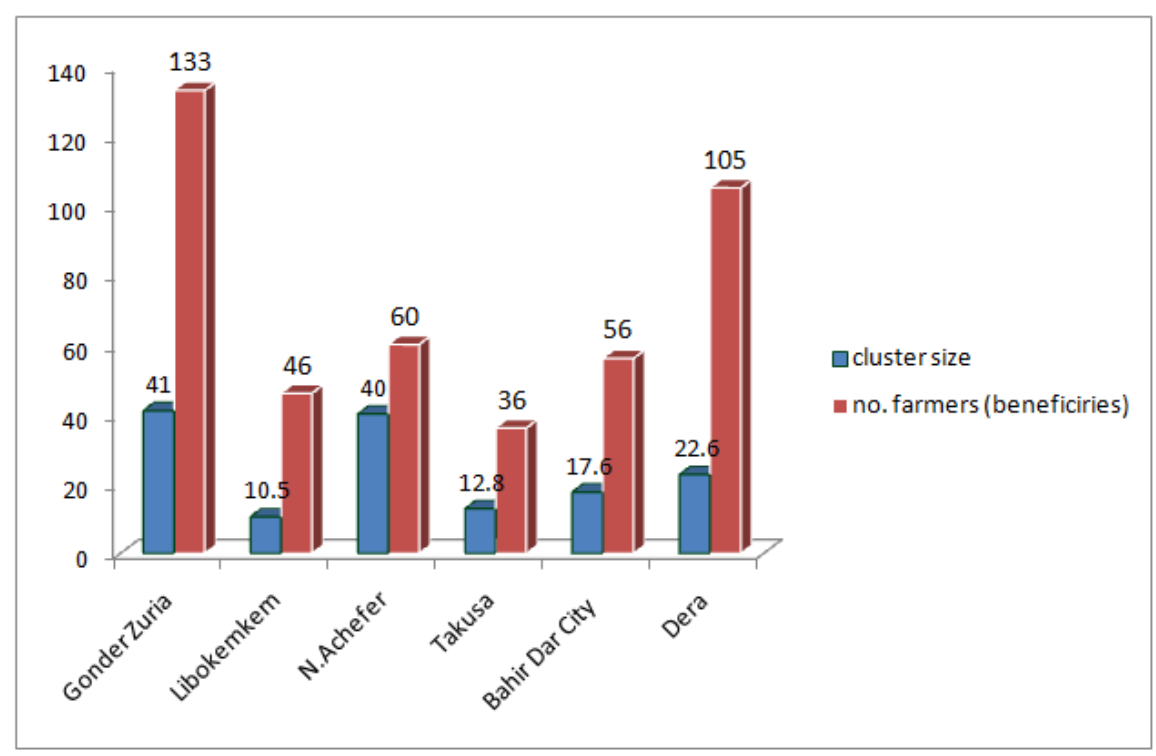

Figure6. Cluster size and beneficiaries disaggregated by districts 


\subsection{Productivity across Intervention Districts}

Yield measurement has been undertaken on demonstrated varieties using quadrant estimation method. Based on this estimation of productivity per hectare,across districts both improved varieties (Shaga and/orWanzaye) had been by far betterthan the local ones. Withinthe districtshaga is better than wanzye variety between improved varieties in terms of productivity. The highest yield (approximately 62 quintals per ha) was recorded in Dera district from shaga variety and followed by 59 quintals in Gondar zuria district from the same variety. On the other hand the lowest yield of shaga variety recorded in Takusa (37 quintals per ha) which was due to the fact that animal pest(hippopotamus) affected rice production around cluster areas of lakeTana. The same amount of productivity has been recorded from Wanzaye variety in both Dera and Gondar zuria districts. Productivity of both varieties was lower in Tis Abay due to lack of application of chemical fertilizers and weeding problem.

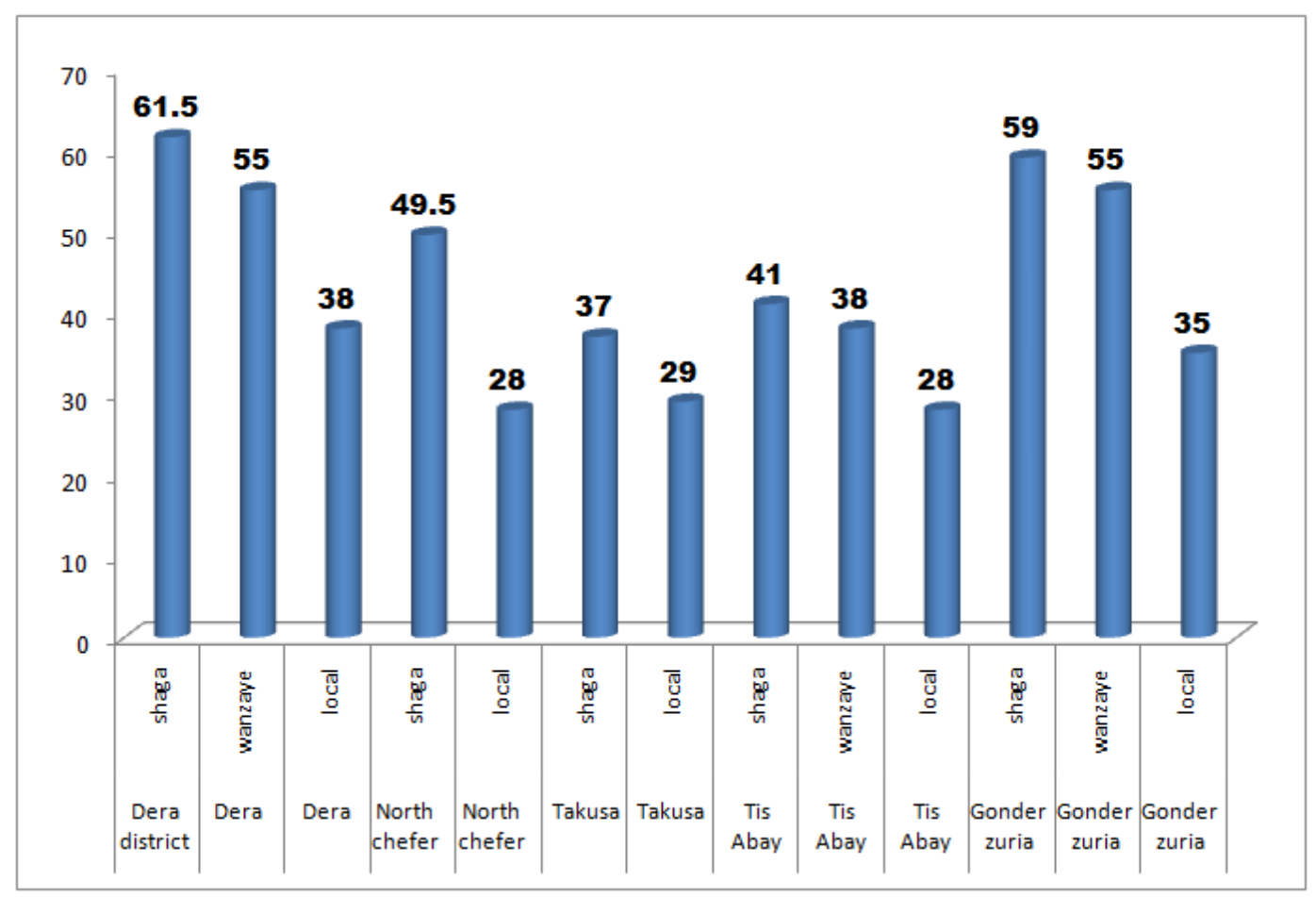

Figure7. Productivity of improved and locally available varieties across intervention districts

\subsubsection{Individual samples test}

Individual test on productivity has been undertaken using t-test statistics against on the information obtained from Ethiopian Central Statistical Agency (CSA) and Zonal level agricultural offices about the average value of productivity on improved varieties (namelyShaga and Wanzaye) and locally available variety. In this case the null hypothesis was the distribution of productivity of Shaga variety at farmers' field was the same with the value obtained from documented sources of CSA in 2020. The research hypothesis which is the interest of researchers who need to test was the distribution or average value of productivity of Shaga variety is not the same with the value taken from CSA and/or Zonal agricultural office. Therefore, the result on the table 1 shows the productivity of Shagaand Wanzayevarieties was significantly different from the productivity recorded by CSA and Zonal agricultural offices. The productivity of local variety at farmers' field was also significantly different from other documented sources by organizations.

Table1. Individual sample test of productivity among improved varieties (Shaga and Wanzaye) and local variety

\begin{tabular}{|l|l|l|l|l|}
\hline \multirow{2}{*}{ Variables } & \multicolumn{3}{|c|}{ Test value = 30 } & p-value \\
\cline { 2 - 5 } & $\mathbf{t}$ & mean & S.E & $0.066^{*}$ \\
\hline $\begin{array}{l}\text { Productivity of improved (Shagavariety) } \\
\text { at farmer's field }\end{array}$ & 3.691 & 53.8 & 6.457 & $0.076^{*}$ \\
\hline $\begin{array}{l}\text { Productivity of improved (Wanzaye } \\
\text { variety) at farmer's field }\end{array}$ & 3.412 & 49.3 & 5.667 & \\
\hline
\end{tabular}


Large Scale Demonstration of Improved Rice Technologies towards Commercialization through Cluster Approach in the Districts of Lake Tana belt, North Western Ethiopia

\begin{tabular}{|l|l|l|l|l|}
\hline Variable & \multicolumn{4}{|l|}{ Test value = 16 } \\
\hline $\begin{array}{l}\text { Productivity of local variety at farmers' } \\
\text { field }\end{array}$ & 5.963 & 33.67 & 2.963 & $0.027 * *$ \\
\hline
\end{tabular}

*significant at 10\% level of significance, ** Significant at 5\% level of significance

\subsubsection{One way analysis of variance on productivity of different varieties}

Test of homogeneity of variances, The assumption of homogeneity of variances on the population from which the samples are drawn is met by using Levene statistical test, $\mathbf{F}(\mathbf{2 , 6})=\mathbf{3 . 1 9}, \mathbf{p}>\mathbf{0 . 0 5}$

\begin{tabular}{|l|l|l|l|}
\hline Levene Statistic & df1 & df2 & Sig. \\
\hline 3.190 & 2 & 6 & 0.114 \\
\hline
\end{tabular}

Test of normality: Shapirowilk method was used to test at 0.001 alpha if the samples of different levels have been drawn from normally distributed population. The result indicates that the two levels of independent variable (shagavariety and local variety) are met the assumption of normality of the population $(\mathbf{p}=\mathbf{0 . 0 8 9}$ and $\mathbf{p}=\mathbf{0 . 5 3 7}<\mathbf{0 . 0 0 1}$ respectively). Howeverwanzaye variety has violated the assumption of normality $(\mathbf{p}=\mathbf{0 . 0 0 0} \leq \mathbf{0 . 0 0 1})$

\begin{tabular}{|c|l|l|l|}
\hline \multirow{2}{*}{ VARIETY } & Shapiro-Wilk & \multicolumn{2}{l|}{} \\
\cline { 2 - 4 } & Statistic & df & Sig. \\
\hline SHAGA & 0.789 & 3 & .089 \\
wanzaye & 0.750 & 3 & .000 \\
local & 0.942 & 3 & .537 \\
\hline
\end{tabular}

There levels were assigned as Shaga (relatively most promisingimproved variety), Wanzaye (relatively more promising improved variety) and local variety (less promising variety). The level of varietiesis significantly different which results toeffect on productivity significantly (table 2), F $(\mathbf{2}, \mathbf{6})$ $=\mathbf{5 . 7}, \mathbf{p}<\mathbf{0 . 0 5}$. The mean values for the three variety levels shows that as the variety level increased (from less promising to more promising to most promising), performance of the variety in terms of productivity would be enhanced (less promising variety: $\mathrm{M}=33.67$; more promising : $\mathrm{M}=49.3$; most promising variety: $\mathrm{M}=53.8$ )

Table2. Analysis of variances among levels of rice varieties

\begin{tabular}{|l|l|l|l|l|l|}
\hline & Sum of Squares & df & Mean Square & F & Sig. \\
\hline Between Groups & 850.889 & 2 & 425.444 & 5.706 & 0.041 \\
\hline Within Groups & 447.333 & 6 & 74.556 & & \\
\hline Total & 1298.222 & 8 & & & \\
\hline
\end{tabular}

The strength ofassociation $\left(\omega^{2}\right)$ between the dependent variable and independent variable (three groups of varieties) accounts for approximately $46 \%$ of the variance on the dependent variable (productivity).

$\omega^{2}=\underline{S S(b e t w e e n ~ g r o u p s)-(K-1)(M S ~ w i t h ~ i n ~ g r o u p s) ~}$

SS (total)+MS(within groups)

$\omega^{2}=\underline{850.889-(3-1)(74.586)}=0.46=46 \%$

$1298.222+74.586$

\subsubsection{Post Hoc Tests and multiple Comparisons}

As mentioned on earlier table 3 , the overallmean difference of three varieties was statistically significant $(\mathrm{p}<0.05$, however this didn't indicate from which varieties the mean differences come from and impacted on the dependent variable (productivity). To do this, Tukey HSD test which is one of Post Hoc comparisontechniques has been employed to test the specific mean difference between varieties. Shaga variety is significantly different from local variety at 0.05 level of significance but not with the variety wanzaye. Wanzaye variety is not statistically different from local variety at 0.05 alpha. The result indicates that the overall difference or effect on productivity is due to the greater significant impact of shaga variety. 
Large Scale Demonstration of Improved Rice Technologies towards Commercialization through Cluster Approach in the Districts of Lake Tana belt, North Western Ethiopia

Table3. post-hoc tests and multiple comparisons

\begin{tabular}{|c|c|c|c|c|c|c|c|}
\hline & (I) VARIE & (J) VARIE & Mean & DifferenceStd. & Sig. & $95 \%$ Confide & Interval \\
\hline & & & $(\mathbf{I}-\mathbf{J})$ & Error & & Lower Bound & Upper Bound \\
\hline & & wanzaye & 4.00 & 7.05 & 0.842 & -17.631 & 25.632 \\
\hline & SHAGA & local & $22.33^{*}$ & 7.05 & 0.044 & 0.7017 & 43.965 \\
\hline & & SHAGA & -4.00 & 7.05 & 0.842 & -25.632 & 17.632 \\
\hline Tukey & wanzaye & local & 18.33 & 7.05 & 0.090 & -3.298 & 39.965 \\
\hline HSD & locol & SHAGA & $-22.33^{*}$ & 7.05 & 0.044 & -43.965 & $0-.702$ \\
\hline & local & wanzaye & -18.33 & 7.05 & 0.090 & -39.965 & 3.298 \\
\hline & $\begin{array}{l}\text { *. The me: } \\
\text { Dependen }\end{array}$ & $\begin{array}{l}\text { n differenc } \\
\text { variable: }\end{array}$ & $\begin{array}{l}\text { is sign } \\
\text { roducti }\end{array}$ & $\begin{array}{l}\text { icant at the } 0.05 \text { l } \\
\text { ity }\end{array}$ & & & \\
\hline
\end{tabular}

\subsection{Summary of Large Scale Demonstration (LSD)}

The table below shows a short and precise summary of zonal

Table4. Intervention areas (clusters, Zones, districts and kebeles, farmers by gender)

\begin{tabular}{|c|c|c|c|c|c|c|c|}
\hline \multirow{2}{*}{ Zone } & \multirow{2}{*}{ District } & \multirow{2}{*}{ Kebele } & \multirow{2}{*}{$\begin{array}{l}\text { No of } \\
\text { Clusters }\end{array}$} & \multirow{2}{*}{$\begin{array}{l}\text { Cluster } \\
\text { Name }\end{array}$} & \multirow{2}{*}{$\begin{array}{l}\text { Cluster } \\
\text { Size } \\
(\mathrm{Ha})\end{array}$} & \multicolumn{2}{|c|}{ Number of farmers } \\
\hline & & & & & & $\mathrm{M}$ & $\mathrm{F}$ \\
\hline \multirow{6}{*}{$\begin{array}{l}\text { Central } \\
\text { Gonder }\end{array}$} & \multirow{6}{*}{ Gonderzuriya } & \multirow{3}{*}{ Abawarka } & \multirow{3}{*}{3} & Abawarka & 5 & 15 & 1 \\
\hline & & & & Gomenge & 5 & 20 & - \\
\hline & & & & Neteba & 5 & 19 & 02 \\
\hline & & \multirow{2}{*}{ Mitireha } & \multirow{2}{*}{2} & Agamye & 10 & 24 & 1 \\
\hline & & & & Dibora & 8 & 31 & 0 \\
\hline & & Gubaye & 1 & Mecheke & 8 & 19 & 01 \\
\hline $\begin{array}{l}\text { South } \\
\text { Gonder }\end{array}$ & Libokemekem & Bura & 1 & Godguadit & 10.5 & 41 & 5 \\
\hline $\begin{array}{l}\text { West } \\
\text { Gojjam }\end{array}$ & Achefer & Legdiya & 1 & Gochakassie & 40 & 56 & 4 \\
\hline $\begin{array}{l}\text { Central } \\
\text { Gonder }\end{array}$ & Takussa & ChachinaAlewa & 1 & $\begin{array}{l}\text { Tijamesk } \\
\text { /gohel }\end{array}$ & 12.75 & 35 & 1 \\
\hline \multirow{2}{*}{\multicolumn{2}{|c|}{$\begin{array}{ll}\text { Bahir Dar } & \text { city } \\
\text { Administration } & \end{array}$}} & \multirow{2}{*}{ Tis abay } & \multirow{2}{*}{2} & Nsanies & 10 & 30 & 2 \\
\hline & & & & Gedelwuha & 7.625 & 23 & 1 \\
\hline \multirow{3}{*}{$\begin{array}{l}\text { South } \\
\text { Gonder }\end{array}$} & \multirow{3}{*}{ Dera } & Jigna & 1 & Gumara & 12.10 & 60 & 4 \\
\hline & & \multirow{2}{*}{ GedamWanzaye } & \multirow{2}{*}{2} & Felegewoyn & 5.5 & 20 & 0 \\
\hline & & & & AbebaAnba & 5 & 20 & 1 \\
\hline \multicolumn{3}{|l|}{ Total } & 14 & & 144.75 & 413 & 23 \\
\hline
\end{tabular}

destinations, districts, peasant associations (PAs), number of cluster locations, name of clusters, size of clusters and beneficiaries under rice Large Scale Demonstration for 2011/2012 E:C cropping season.

\subsection{Farmers and Stakeholders Perception, Preference and Feedbacks}

Some of the key issues raised by farmers and stakeholders during the field day

- Farmers raised that improved rice varieties are better than the local ones due to early seed emergence (within 4-5days ), tillering capacity and early maturity

- Better in terms of disease resistance, biomass and yield performance

- Requested development of varieties which have traits of white in color with high yielding performancedue to the case of price difference during marketing

- They also requested to make available of rice milling machines around their residence 


\section{CONCLUSION AND RECOMMENDATION}

Both varieties are better than local Varity in terms of productivity and fulfilling other parameters such as food quality. However farmers still claim on improvement of the color of rice grain which influences price at the market. Hence breeding research team need to exert their research efforts to release new varieties which have desirable grain color and preferred by producers. As there are still huge and un-tapped potential production areas are available in and around Lake Tana belts, large scale demonstration and wider scaling up activities need to be strengthened. Collaboration and coordination among key stakeholder in rice value chain is paramount importance to enhance rice production and productivity in the region and nationwide.

\section{REFERENCES}

[1] AstewlTakele. 2010. Analysis of rice profitability and marketing chain: The case of Fogeraworeda, South Gondar Zone, Amhara National Regional State, Ethiopia. MSc Thesis. Department of Agricultural Economics, Haramaya University.

[2] (Belay et al., 2006)

[3] CSA (Central Statistical Agency). 2011. Report on Area And Production of Major Crops (Private Peasant Holdings, Meher Season) The Federal Democratic Republic of Ethiopia Central Statistical Agency Agricultural Sample Survey. ADDIS ABABA, Ethiopia.

[4] CSA (Central Statistical Agency). 2013. Report on Area And Production of Major Crops (Private Peasant Holdings, Meher Season) The Federal Democratic Republic of Ethiopia Central Statistical Agency Agricultural Sample Survey. ADDIS ABABA, Ethiopia.

[5] CSA (Central Statistical Agency). 2017. Report on Area And Production of Major Crops (Private Peasant Holdings, Meher Season) The Federal Democratic Republic of Ethiopia Central Statistical Agency Agricultural Sample Survey. ADDIS ABABA, Ethiopia.

[6] DawitAlemu, AgajieTesfaye, AbebawAssaye, Degu Addis, TilahunTadesse and John Thompson. 2018. A HISTORICAL ANALYSIS OF RICE COMMERCIALISATION IN ETHIOPIA: THE CASE OF THE FOGERA PLAIN. A blog posted in Future Agricultures Consortium website. Posted on May 31, 2018. Link: https://www.future-agricultures.org/blog/from-the-fogera-plain-how-one-man-helped-to-build-aregional-industry/

[7] Gebey, T., Berhe, K., Hoekstra, D. and Bogale, A. 2012.Rice value chain development in Fogeraworedabased on the IPMS experience. Nairobi, Kenya: ILRI. 23pp.

[8] (Leloet al., 1995).

[9] MoARD. 2010. National Rice Research and Development Strategy of Ethiopia. The Federal Democratic Republic of Ethiopia, Ministry of Agriculture and Rural development, Addis Ababa, Ethiopia.48 pp.

[10] TilahunTadesse, AbebawAssaye and DawitAlemu. 2018. Ethiopia: Enriching Livelihoods with Rice Research. A blog posted in Future Agricultures Consortium website. Posted on October 5, 2018. Link: https://www.future-agricultures.org/blog/ethiopia-enriching-livelihoods-with-rice-research/

Citation: Misganaw Anteneh, et.al., " Large Scale Demonstration of Improved Rice Technologies towards Commercialization through Cluster Approach in the Districts of Lake Tana belt, North Western Ethiopia" International Journal of Research Studies in Agricultural Sciences (IJRSAS), 2020; 6(12), pp. 12-20, https://doi.org/10.20431/2454-6224.0612002

Copyright: () 2020 Authors. This is an open-access article distributed under the terms of the Creative Commons Attribution License, which permits unrestricted use, distribution, and reproduction in any medium, provided the original author and source are credited. 